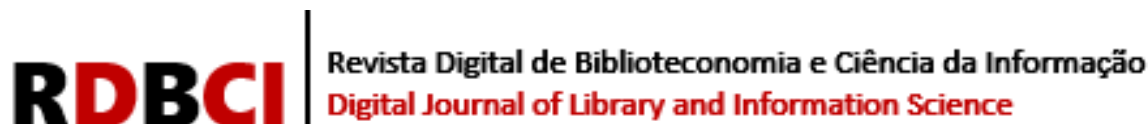

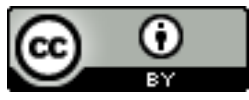

\section{Convergências entre a teoria da troca social e a mediação da informação e do conhecimento na perspectiva dos desenvolvedores de software um estudo de caso}

\author{
Leonardo Pereira Pinheiro de Souza ${ }^{1}$ iD https://orcid.org/0000-0001-5452-8060 \\ João Arlindo dos Santos Neto ${ }^{2}$ iD https://orcid.org/0000-0003-1833-911X \\ Cássia Regina Bassan de Moraes ${ }^{3}$ iD https://orcid.org/0000-0001-6285-5117 \\ ${ }^{1}$ Universidade Estadual Paulista, Marília, SP, Brasil / e-mail: leopinheirodesouza@gmail.com \\ ${ }^{2}$ Universidade Estadual de Londrina, Londrina, PR, Brasil / e-mail: santosneto@uel.br \\ ${ }^{3}$ Universidade Estadual Paulista, Marília, SP, Brasil / e-mail: crbassan@ gmail.com
}

\section{RESUMO}

Informação e conhecimento são imprescindíveis à sobrevivência das empresas e no cotidiano das pessoas. Ademais, o software é elemento fundamental para gerir essas informações. Os profissionais de programação fazem uso de informação e conhecimento organizacional para desenvolverem seus projetos e trabalharem em equipe. Informação e conhecimento representam poder, e seu compartilhamento inclui barganhas, comportamentos estudados pela Teoria da Troca Social. Compartilhar informação efetivamente envolve mais do que repassá-la, envolve uma interferência visando que o receptor faça sua apropriação, para a execução do trabalho, por meio de sujeitos mediadores da informação. Objetiva-se verificar como se dá o compartilhamento de informação e conhecimento entre profissionais de software, inferindo como princípios da Teoria da Troca Social interferem ou em sua mediação, destacando a influência de motivadores egocêntricos e altruístas, ou voltados à coletividade. Como procedimentos metodológicos, efetuou-se um estudo de caso, de natureza descritiva, com profissionais de software discentes de uma instituição pública de ensino superior, de Garça, São Paulo, bem como seus funcionários administrativos, utilizando questionários, entrevistas e análise do site da instituição. Como resultados, verificou-se existirem evidências de mediação da informação e conhecimento entre os pesquisados, sendo que motivações altruístas e egocêntricas se conciliam dialeticamente nessa /mediação/compartilhamento. Atribui-se os resultados possivelmente a valores internalizados na formação universitária e a um ambiente de trabalho psicologicamente positivo. Conclui-se que existem convergências entre a Teoria da Troca Social e a mediação da informação, tanto no aspecto teórico quanto prático, evidenciando a possiblidade da mediação além dos equipamentos informacionais tradicionais: bibliotecas, arquivos e museus.

\section{PALAVRAS-CHAVE}

Programação. Mediadores da informação. Conhecimento organizacional. 


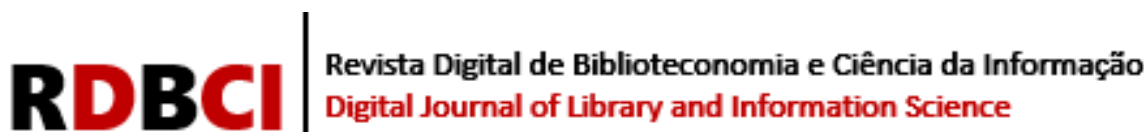

\section{Convergences between social exchange theory and mediation of information and knowledge from the perspective of software developers

\author{
a case study
}

\begin{abstract}
Information and knowledge are essential for the survival of companies and people's daily lives. Furthermore, software is a fundamental element to manage this information. Programming professionals use information and organizational knowledge to develop their projects and work as a team. Information and knowledge represent power, and their sharing includes bargains, behaviors studied by the Social Exchange Theory. Sharing information effectively involves more than passing it on, it involves interference aiming the receiver's appropriation of it, for work execution, by means of information mediating subjects. This paper objective is to verify how information and knowledge are shared among software professionals, inferring how principles of Social Exchange Theory interfere or not in their mediation, highlighting the influence of egocentric and altruistic motivators, or motivation aimed at the group. As methodological procedures, a descriptive case study was carried out with software professionals, students of a public higher education institution, in Garça city, São Paulo state, as well as their administrative personnel, using questionnaires, interviews and analysis of the institution website. As a result, it was found that there is evidence of mediation of information and knowledge among those surveyed, since altruistic and egocentric motivations are dialectically reconciled in this mediation/sharing. The results are attributed possibly to internalized values during higher education period, as well to a psychologically positive work environment. It is concluded that there are convergences between the Social Exchange Theory and the mediation of information, both in theoretical and practical aspects, showing the possibility of mediation besides traditional informational equipment: libraries, archives and museums.
\end{abstract}

\section{KEYWORDS}

Programming. Information mediators. Organizational knowledge.

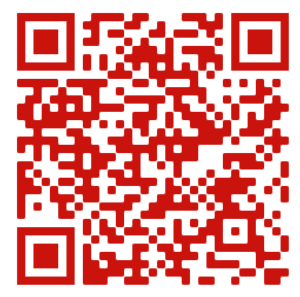

JITA: GD. Organizations 


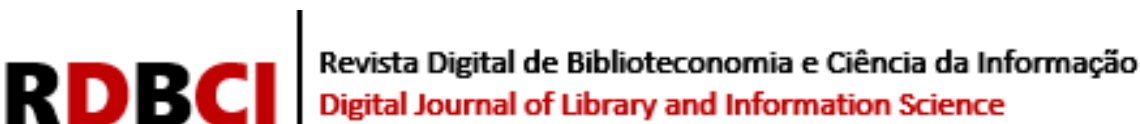

\section{INTRODUÇÃO}

As tecnologias da Informação e da Comunicação (TIC) se tornaram a pedra fundamental da vida moderna, em que um fluxo de informação constante e acelerado é requisito imprescindível para a sobrevivência de praticamente todos os tipos de organizações. A área de softwares tem expressiva relevância no aspecto econômico em geral. Segundo a Associação Brasileira das Empresas de Software (2020), esse setor movimentou cerca de 44,3 bilhões de dólares americanos no Brasil, em 2019, sendo que nesse ano o crescimento do setor nacionalmente superou inclusive a média mundial.

A interação dos seres humanos com os aparatos tecnológicos se dá por meio dos softwares, que são conjuntos de instruções em linguagem de programação que determinam como diversos tipos de dispositivos devem receber, processar, armazenar e exibir a informação. O software, comumente, tem uma estrutura complexa, constando de várias camadas de funcionalidades e módulos interdependentes, que são criados e mantidos por equipes de profissionais de diversas especialidades (SOUZA, 2019). A atividade de programação, portanto, requer perícia e criatividade, exigindo a criação, o uso e compartilhamento constante de informação e conhecimento, para que a equipe de desenvolvedores possa trabalhar de maneira coesa (SOMMERVILLE, 2007).

O conhecimento é inextricavelmente humano, elaborado na mente do sujeito, num amálgama de suas experiências passadas com informações por ele adquiridas, juntamente com seus valores e visão de mundo. Esse conhecimento, enquanto permanece como experiência pessoal, se caracteriza como um elemento rico, complexo e subjetivo, que é difícil de expressar diretamente a outros, caracterizando-se como tácito (TAKEUCHI; NONAKA, 2008). Esse saber tácito pode também ser codificado, expresso em palavras ou símbolos, na sua forma explícita, ou, como define Buckland (1991), conhecimento-como-informação. A relação entre informação e conhecimento, portanto é íntima e as transformações entre esses dois elementos, a conversão de um em outro, é um processo cíclico.

Como já mencionado, para trabalhar em equipe, é preciso que haja compartilhamento de informação e conhecimento. Contudo, há dois aspectos principais que podem dificultar esse compartilhamento. Primeiramente, como já discorrido, o conhecimento na forma tácita é pessoal, e existe a necessidade de que seu detentor queira efetivamente compartilhá-lo. Segundo, o conhecimento explícito, convertido em informação, pode representar poder e prestígio para seu detentor no contexto organizacional (PÉREZ-MONTORO-GUTIÉRREZ, 2008). Portanto, é uma tarefa complexa tentar compreender que fatores e motivações podem levar os sujeitos a ceder preciosos conhecimentos e informações a outras pessoas. Neste aspecto, a Teoria da Troca Social (TTS) pode ajudar na compreensão desse fenômeno complexo.

\footnotetext{
A TTS descreve as interações comportamentais entre dois ou mais indivíduos e como essas interações comportamentais reforçam o comportamento do outro. Ambos os atores efetuam trocas uns com os outros com a crença de que essas trocas produziriam benefícios para ambos (ZOLLER; GARLAND; MULDON, 2019. p. 50, tradução nossa).
}

A TTS utiliza aportes da Sociologia, Economia, Psicologia e outras áreas para explicar os mecanismos de troca de benefícios entre pessoas que não envolvam transações monetárias, motivadas por relacionamentos de longo prazo e/ou normas sociais. Ademais, pode-se, também, classificar os fatores motivadores da TTS entre motivações egocêntricas, voltadas à reciprocidade direta ao sujeito que provê quaisquer benefícios aos outros (CROPANZANO; MITCHELL, 2005; GIFT EXCHANGE, 2020; ZOLLER; GARLAND; MULDON, 2019), 


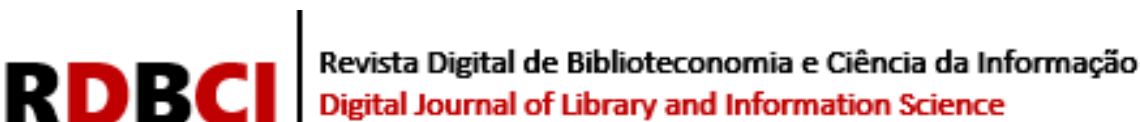

como também motivações altruístas e voltadas ao bem-estar coletivo (FOA; FOA, 1974, 1980 apud CROPANZANO; MITCHELL, 2005; LAWLER; TYE, 1999; TSAI; CHENG, 2011; CHESHIRE, 2020).

Justifica-se a presente pesquisa pelo fato apontado por Hall (2003), de que trabalhos em CI sobre o compartilhamento de informação e conhecimento geralmente se fundamentam em resultados empíricos, sem uma base teórica mais sólida para explicar o sentido profundo desse compartilhamento. Enfatiza-se que este autor (2003) recomenda explicitamente o emprego da TTS para conferir maior consistência nas pesquisas sobre a temática mencionada. A TTS estuda as relações de troca desde longa data, a exemplo da importante pesquisa sobre trocas de presentes em sociedades primitivas, realizada pelo sociólogo e antropólogo Marcel Maus, na década de 1920 (GIFT EXCHANGE, 2020). Aproveitar esses aportes teóricos torna possível uma "[...] compreensão mais profunda dos fenômenos, sem recriar conceitos a partir do 'zero', permitindo um avanço mais consistente na pesquisa”' (MORAES; SOUZA, 2019).

Neste respeito, o sujeito que compartilha informação e conhecimento age como seu mediador. A mediação da informação é um processo de interferência sobre a informação, de modo direto/explícito, ou indireto/implícito, que visa que outro(s) sujeito(s) possam realizar a efetiva apropriação, ou compreensão, dessa informação (ALMEIDA JÚNIOR, 2015). Para que a mediação ocorra, portanto, é preciso que o mediador tenha o genuíno interesse de que o receptor da informação tenha condições de apropriar-se dela, representando um ato em prol da autonomia e empoderamento do outro, um ato de cuidar (GOMES, 2014).

Portanto, e de acordo com a problemática exposta, os problemas de pesquisa centram-se nos seguintes questionamentos: quais as principais motivações que levam profissionais de software a compartilharem informação e conhecimento com seus colegas? Existe alguma preocupação por parte deles de que seus colegas façam a efetiva apropriação da informação? Há evidências da existência da mediação da informação entre os desenvolvedores de software? Tendo em vista tais questionamentos, a presente pesquisa tem como objetivo geral verificar como se dá o compartilhamento de informação e conhecimento entre profissionais de software, sob a ótica da TTS. Busca-se, ainda, identificar como os princípios motivacionais, tanto voltados à coletividade e ao altruísmo, quanto voltados à reciprocidade direta/egocentrismo, colaboram ou não para a mediação efetiva da informação nesse âmbito. Para a consecução dos objetivos propostos, efetuou-se uma pesquisa quali-quantitaiva desvelando a perspectiva dos desenvolvedores de software concernente à problemática já abordada, tendo como contexto uma instituição pública de ensino superior em que esses trabalhadores são discentes. A referida instituição acolhe estudantes de vários municípios da região de Marília, São Paulo, tendo relevante impacto socioeconômico.

\section{REFERENCIAL TEÓRICO}

Desenvolver softwares é um trabalho intensivo não só no uso de informação e conhecimento, como também de interação humana (SOUZA, 2019). A sequência de passos para se produzir um software é chamada de processo de software. Embora exista uma miríade de diferentes metodologias para criar software, todas elas compartilham um núcleo de atividades comuns: levantar características do software e funcionalidades com o cliente; planejar a estrutura do software; implementá-lo usando linguagens de programação; realizar testes; efetuar ajustes e correções ao longo do tempo (SOMMERVILLE, 2007). Como afirma Souza (2019), nesse processo são intercambiados: informação registrada/conhecimento explícito por meio de documentação de projetos entre a equipe de desenvolvimento; experiências em forma de conhecimento tácito também entre membros da equipe de 


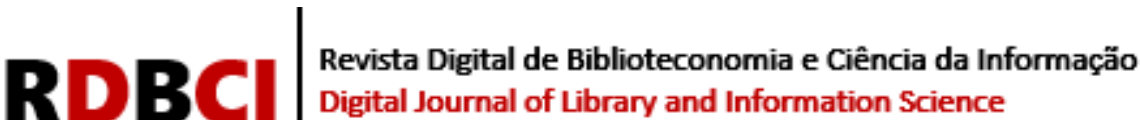

desenvolvimento; conhecimentos tácitos sobre regras de negócio entre desenvolvedores e clientes.

Para Park, Lee e Lee (2015), compartilhar informação e conhecimento é vital para o sucesso de um projeto de software, inclusive reduzindo bastante o tempo requerido para a resolução de problemas. Ademais, o fluxo de informação e conhecimento se faz imprescindível para integrar de modo harmônico as atividades de profissionais de diversas funções/formações que trabalham em aspectos específicos da estrutura do software.

\begin{abstract}
Os projetos de Sistemas de Informação (SI) precisam de intensivas contribuições de conhecimento de profissionais com diferentes especialidades. Uma variedade de conhecimentos no campo comercial precisa ser integrada e convergida com uma variedade de conhecimentos tecnológicos para criar sistemas de informação apropriados. Esses especialistas podem residir em diferentes partes da organização ou em diferentes organizações, intensificando o problema do compartilhamento de conhecimento (PARK; LEE; LEE, 2015, p. 194, tradução nossa).
\end{abstract}

Visto que o conhecimento e a informação são recursos preciosos, e podem representar vantagens pessoais para seus detentores, é preciso entender quais fatores poderiam estimular os sujeitos a compartilharem com outros. Defende-se que a TTS pode apresentar explicações satisfatórias nesse respeito.

Inicialmente, é relevante destacar que as relações de intercâmbio de benefícios no contexto da TTS podem acontecer tanto de um sujeito para outro, como também do sujeito para o grupo em que está inserido. Os mecanismos da TTS não envolvem transações em dinheiro, como já mencionado. O princípio básico da TTS pode ser melhor compreendido quando se analisa as práticas cerimoniais de trocas de presentes nas sociedades primitivas. A troca de presentes se refere ao intercâmbio de bens ou serviços entre sujeitos de modo voluntário, em rituais religiosos ou cerimônias, como parte do comportamento social esperado, reafirmando um relacionamento prévio entre as partes ou como modo de iniciar um relacionamento, tendo como saldo o prestígio, em vez de vantagens materiais (GIFT EXCHANGE, 2020). Um aspecto fundamental dessa prática é a necessidade de reciprocidade nas trocas, como símbolo de amistosidade, para que o bom relacionamento possa ser mantido.

O ciclo de troca de presentes implica obrigações de dar, receber e retornar. Podem existir sanções para induzir as pessoas a dar, desaprovar ou perder prestígio resultante de uma falha em fazê-lo. A recusa em aceitar presentes pode ser vista como recusa nas relações sociais e pode levar à inimizade. A reciprocidade do ciclo está na obrigação de devolver o presente; o prestígio associado à aparência de generosidade determina que o valor do retorno seja aproximadamente igual ou superior ao valor do presente original (GIFT EXCHANGE, 2020, tradução nossa).

Portanto, convenciona-se na presente pesquisa denominar os motivadores da TTS voltados à reciprocidade direta, visando benefícios pessoais imediatos, de motivações egocêntricas. Entretanto, as relações humanas nem sempre são construídas embasadas no interesse por retribuições diretas.

Em diversas ocasiões pessoas proveem seus recursos ou esforços em benefício de seu grupo, ou até mesmo de desconhecidos, sem que haja perspectivas claras de uma retribuição. A teoria da troca generalizada pode iluminar os motivos desse tipo de comportamento. Essa modalidade de TTS pode ocorrer entre organizações, nações, grupos sociais, até mesmo entre pessoas que não se conhecem, sendo que aquele que provê o benefício está ciente de que uma reciprocidade direta pode não ser possível (CHESHIRE, 2020). Este é uma espécie de comportamento altruísta, no qual o sujeito pode ter a expectativa de que fazendo algo bom a alguém, quando necessitar, alguém também poderá fazer algo por ele. Como afirma Cheshire (2020), uma forma bastante comum de troca generalizada ocorre quando os sujeitos fazem 


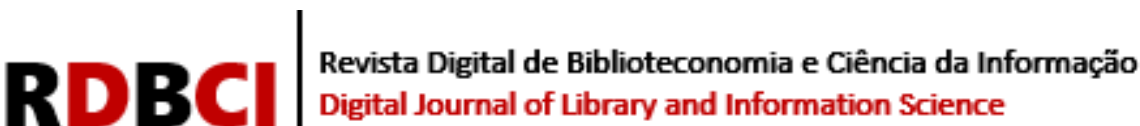

colaborações para o bem comum ou público, também chamada de troca focada no grupo, em que todos se beneficiam.

Em relação à TTS em si, as relações de troca em seu âmbito são constituídas de três elementos básicos: normas/regras; recursos trocados; relacionamento entre as partes envolvidas (CROPANZANO; MITCHELL, 2005). Concernente ao relacionamento, no âmbito da TTS, este deve se basear em interações de longo prazo, que resultam em sólidos laços de confiança e comprometimento entre os sujeitos (CROPANZANO; MITCHELL, 2005). Essa afirmação pode ser confirmada no sentido em que diversos autores asseveram que, justamente pelo conhecimento ser um elemento precioso, e pessoal, quando se trata da vertente tácita, especialmente, que é preciso confiar na pessoa com quem se compartilha, de que essa pessoa não vá se aproveitar do conhecimento de maneira indevida e/ou prejudicar outrem (MARCHAND; KETTINGER; ROLLINS, 2001; SOUZA, 2019; TAKEUCHI, NONAKA, 2008). Essa confiança leva tempo para ser construída, conforme os sujeitos vão conhecendo o comportamento e os valores uns dos outros.

Sobre as regras de troca, estas podem se basear tanto na reciprocidade quanto em acordos negociados. Para Cropanzano e Mitchell (2005), uma tendência maior ou menor à reciprocidade tem a ver tanto com características psicológicas do sujeito, quanto com sua cultura, sendo possível também a existência de reciprocidade por atos negativos recebidos, sendo que esta última pode ser inibida por crenças morais/religiosas do sujeito, ou em uma 'lei do retorno' intrínseca à realidade. Pode-se, assim, inferir o possível impacto de princípios morais/religiosos internalizados quando o sujeito concede um benefício a outrem sem esperar reciprocidade direta, ou até mesmo nenhuma reciprocidade. Por exemplo, Cheshire (2020) afirma que em sociedades primitivas os sacrifícios, dádivas e libações eram encarados como presentes por aqueles que esperavam receber favores dos deuses. Assim, atos de bondade são ainda encarados como um modo de granjear o favor de Deus nas religiões modernas.

Ainda referente ao tema da reciprocidade, e as interações entre os sujeitos, estas determinam, em muitas ocasiões, que o intercâmbio de conhecimento e informação funcione quase como uma transação de compra e venda. Pérez-Montoro-Gutiérrez (2008) discorre que nas organizações ocorre um 'mercado do conhecimento', no qual: o conhecimento seria a 'mercadoria'; os compartilhadores, seus 'vendedores'; os gestores, os intermediários; a reciprocidade e a boa reputação que pode ganhar o compartilhador, o 'preço' do seu saber. Para Pérez-Montoro-Gutiérrez (2008), as transações de conhecimento estariam debaixo das mesmas leis econômicas que regem os mercados reais, como oferta e demanda, entre outras. Contudo, como se discutirá mais adiante na presente seção, nem sempre as interações de conhecimento acontecem motivadas apenas pelo ganho pessoal.

Por fim, é preciso discorrer sobre os acordos, ou regras, negociados. Esses têm um caráter mais formal que a simples troca de gentileza entre amigos ou colegas, estando ainda mais próximos de transações financeiras, no sentido de que os termos e 'valores' dos itens intercambiados são mais detalhadamente descritos, por vezes até mesmo assentados contratualmente (CROPANZANO; MITCHELL, 2005). Essa perspectiva, contudo, difere da dos mercados de conhecimento, acima apresentada, no sentido de que no mercado de conhecimento organizacional não há uma definição formal do 'preço' do saber de alguém nem acordos detalhados; o 'valor' é dado subjetiva e tacitamente.

A natureza dos itens que podem ser intercambiados no contexto da TTS é bastante ampla, indo desde elementos físicos até abstratos. Os itens intercambiados, afirmam Foa e Foa (1974, 1980 apud CROPANZANO; MITCHELL, 2005) podem ser, por exemplo: informação, amor, status, bens ou serviços.

Reitera-se que, para Pérez-Montoro-Gutiérrez (2008), o conhecimento intercambiado na organização tem um 'preço' simbólico, que pode se constituir em duas principais categorias: 


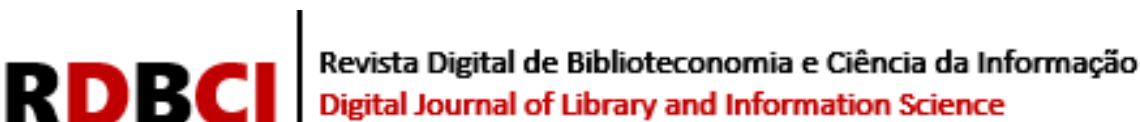

a reciprocidade e a reputação. O tema reciprocidade já foi bastante discutido no presente trabalho. Espera-se, portanto, que o sujeito que partilha seus conhecimentos poderá dar preferência àquelas pessoas com mais condições de lhe pagarem em conhecimentos valiosos no futuro (PÉREZ-MONTORO-GUTIÉRREZ, 2008). Manter uma boa reputação no grupo também é outro motivador comum para ceder conhecimentos.

\begin{abstract}
Por um lado, em um sentido positivo, se tem a expectativa de que, ao cedê-lo, outras pessoas o reconhecerão (adquirirá a reputação) duplamente, como possuidor de conhecimentos valiosos e como indivíduo que apresenta a disposição positiva de compartilhá-los para o bem da organização. E por outro, em um sentido negativo, se tem a percepção de que não compartilhar [...] pode criar uma má imagem dele dentro da organização (PÉREZ-MONTORO-GUTIÉRREZ, 2008, p. 101, tradução nossa).
\end{abstract}

Contudo, como já discutido na presente seção, não só a reputação e a reciprocidade podem ser trocadas numa relação de TTS, mas também amor, amizade e afins. Ou seja, infere-se que um sujeito possa ceder conhecimento e informação a alguém que pode não estar em condições de retribuir a altura, tanto porque busca sua amizade, seu companheirismo, ou porque sente algum impulso moral de ajudar ao próximo. Estendendo esse raciocínio, pondera-se que: "Sejam dois amantes que compartilham um afeto caloroso e mútuo ou duas empresas que reúnam recursos para gerar um novo produto, a forma básica de interação permanece a mesma" (LAWLER; TYE, 1999, p. 217, tradução nossa).

Existe mais um aspecto a ser considerado com relação à disposição de compartilhar informação e conhecimento, que diz respeito a confiar na própria capacidade de gerar/compartilhar esses itens: a autoeficácia. A autoeficácia é definida como uma confiança que o indivíduo tem na própria capacidade de ser bem-sucedido em executar comportamentos que levem a resultados pretendidos (BANDURA, 1978). A percepção da própria capacidade cognitiva se torna um motivador na interação com outras pessoas, visando o compartilhamento/mediação dos recursos intelectuais.

Usuários com alto nível de autoeficácia sentirão que são competentes para compartilhar, contribuir e trocar seu conhecimento em uma comunidade [...]. Portanto, seus comportamentos de participação são prováveis de serem gradualmente promovidos (BAO; HAN, 2019, p. 642, tradução nossa).

Pode-se inferir do citado acima que o sujeito pode fruir certo prazer em demonstrar sua capacidade aos demais, ou apenas exercitar suas habilidades cognitivas, como no caso daqueles que se entretêm com qualquer jogo/diversão intelectualmente estimulantes.

Até o momento, discutiu-se os ganhos pessoais concernentes à TTS. Contudo, as trocas podem ser realizadas também visando ganhos para o grupo. Como já mencionado na presente seção, a troca generalizada ocorre quando o sujeito provê um benefício não a uma pessoa específica, mas para toda a coletividade de que faz parte. Argumenta-se que esta modalidade de TTS é especialmente relevante, pois permite que o conhecimento e a informação sejam difundidos por toda a organização, contribuindo para a consecução de seus objetivos. Para Tsai e Cheng (2011), colaboradores sentem-se dispostos a compartilhar seus saberes em prol da organização quando sentem que esta age de modo justo com eles. Ademais, Souza e Moraes (2018) concluem que quando a organização se interessa no bem-estar dos colaboradores, é criado um ambiente em que vigora a satisfação e um clima organizacional positivo, ou seja, uma atmosfera psicológica favorável ao compartilhamento de conhecimento. Portanto, infere-se que o clima organizacional é um importante elemento motivacional.

o conceito de clima organizacional representa o quadro mais amplo da influência ambiental sobre a motivação. O clima organizacional é a qualidade ou propriedade do ambiente organizacional que é percebida ou experimentada pelos participantes da 


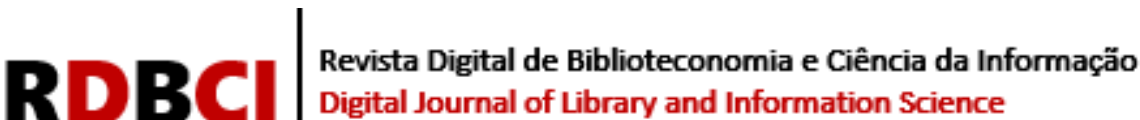

organização e que influencia o seu comportamento (CHIAVENATO, 2003, P. 539).

No contexto da TTS é como se houvesse uma reciprocidade entre colaborador e empresa, na troca de benefícios mútuos. "Além disso, é mais provável que um funcionário mais comprometido com a organização e mais confiante na gerência e nos colegas de trabalho compartilhe seus conhecimentos" (TSAI; CHENG, 2011, p. 1076, tradução nossa).

$\mathrm{O}$ aspecto emocional é bastante relevante quando se considera as interações no contexto da TTS. O apreço, a amizade e o hábito de cuidar dos companheiros de trabalho que precisam de ajuda é um impulso natural em seres humanos e se reflete também no contexto organizacional (CROPANZANO; MITCHELL, 2005; ZOLLER; GARLAND, 2019). A mediação da informação é também um ato de cuidado e de apreço, pois o mediador precisa fazer mais do que apenas repassar informação, mas certificar-se de que ela é útil para o receptor e que há condições de que ele possa efetivamente compreendê-la.

\footnotetext{
Se a ação mediadora é uma ação ligada ao movimento e a vida, considerando-se que os sujeitos que necessitam de informação, e com os quais os profissionais da informação interagem, precisam sentir acolhimento, precisam desenvolver um sentimento de pertença ao ambiente informacional, então é preciso admitir que o mediador da informação é um agente envolvido com o ato de cuidar (GOMES, 2014, p. 53).
}

Mediar informação e conhecimento pode ser encarado como um ato de apreço pelo outro. Além dos ganhos pessoais mais concretos que essa atividade pode resultar, ela pode ser efetuada também visando ganhos emocionais, visto a necessidade intrínseca de todo ser humano por afeto e reconhecimento, que pode obter do outro, a quem a informação é mediada. Isto torna possível que alguém medeie informação aparentemente sem pedir nada em troca, enquanto anseia os benefícios psicológicos de ajudar ao próximo.

Portanto, mediante a revisão de literatura e as discussões apresentadas na presente seção, pode-se sumarizar os principais elementos motivadores da TTS intervenientes no compartilhamento e mediação da informação e do conhecimento. São eles: benefícios pessoais diretos (reciprocidade direta); benefícios coletivos e indiretos (troca generalizada, resultante do clima organizacional positivo); benefícios emocionais (amizade, companheirismo, amor e afins); prazer intelectual/ exercício da autoeficácia.

Além dos aspectos positivos da colaboração entre sujeitos organizacionais, considerados pela TTS, é preciso esclarecer que há, no âmbito organizacional, comportamentos negativos que dificultam tanto o compartilhamento como a mediação de informação e conhecimento. Reitera-se que o modo como o colaborador é tratado pela empresa e o nível em que esta satisfaz suas necessidades físicas e psicossociais, constituindo o clima organizacional, já abordado na presente seção, influencia a motivação dos colaboradores. A insatisfação das referidas necessidades provoca o que se denomina moral organizacional baixo, cujas implicações, dentre outras, são: “[...] atitudes de desinteresse, negação, rejeição, pessimismo e apatia em relação ao trabalho, além de problemas de supervisão e de disciplina" (CHIAVENATO, 2003, p. 120). Seguindo a lógica inversa dos princípios da TTS, infere-se que, se o sujeito é motivado a colaborar com a organização provendo informações e conhecimentos como retribuição ao bom tratamento recebido (TSAI; CHENG, 2011), a demonstração de desinteresse da empresa pelas necessidades do funcionário é paga com a apatia deste.

Outros fatores ligados ao moral e clima organizacionais negativos podem funcionar como obstáculos no compartilhamento de informação, como: a desconfiança em relação aos colegas e a monopolização de informação, como modo de obter sucesso na carreira (DAVENPORT; PRUSAK, 1998). O monopólio de informação e conhecimento pode ser uma 


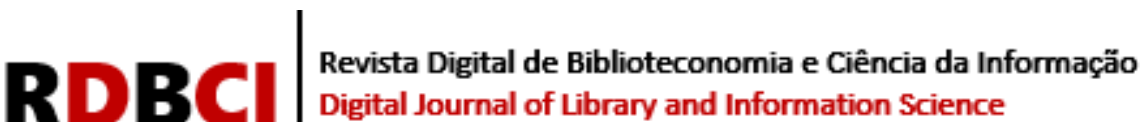

estratégia de defesa do sujeito quanto a incertezas sobre sua estabilidade na empresa, como discute Terrett (1998), em relação aos profissionais de advocacia:

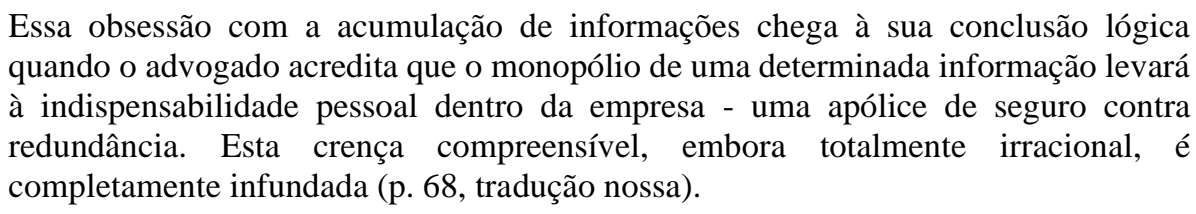

Embora existam esses fatores que prejudicam o compartilhamento e potencial mediação da informação e do conhecimento, a natureza colaborativa e interfuncional da atividade de desenvolvimento de software exige um mínimo de compartilhamento para que os profissionais possam integrar os distintos módulos/camadas de software de que são responsáveis para se obter um produto funcional (SOMMERVILLE, 2007; SOUZA, 2019). Como analogia, infere-se que a interface gráfica criada pelo profissional ' $A$ ' precisa integrar-se satisfatoriamente à camada de funcionalidades criada pelo profissional 'B', que deve acoplar-se corretamente ao banco de dados elaborado pelo profissional ' $\mathrm{C}$ '. Caso contrário, o sistema desenvolvido não conseguirá executar as tarefas que lhe são requeridas. Partindo-se do princípio de que forçosamente deve haver algum tipo de compartilhamento de informação e conhecimento nesse nicho profissional, a questão é verificar qual o nível de qualidade/efetividade desse compartilhamento, possibilitando a execução eficaz do trabalho. Defende-se que evidências de possíveis comportamentos de mediação da informação e do conhecimento possam funcionar como indicadores dessa qualidade e efetividade, já que mediar envolve mais do que repassar informação, mas compartilhar a informação adequada para a satisfação efetiva das necessidades do sujeito, certificando-se de que ele tenha condições de compreendê-la, apropriar-se dela.

\section{PROCEDIMENTOS METODOLÓGICOS}

A presente pesquisa caracteriza-se como básica, do tipo exploratório-descritivo (GIL, 2008), pois visa descrever as características dos fenômenos do compartilhamento de informação e conhecimento, e sua possível mediação, numa determinada população, expondo características do ambiente educacional que forjou os valores/práticas desses profissionais. Além disso, se estabelece a relação entre os tipos de comportamentos de TTS e a possível mediação da informação e do conhecimento entre os sujeitos pesquisados.

Ademais, adota como método de pesquisa o estudo de caso único com abordagem quali-quantitativa. Para Yin (2009), os estudos de caso são uma modalidade de pesquisa ideal para investigar fenômenos sociais complexos, baseando-se na investigação de poucas unidades de análise, porém em certo grau de profundidade, pelo cruzamento de variadas fontes de evidência. A generalização dos resultados, neste caso, não se embasa em critérios quantitativos, mas é analítica, verificando as convergências dos dados coletados das unidades de análise entre si e com a literatura precedente, visando aprofundar ou expandir aportes teóricos (YIN, 2009). Este é um paradigma de pensamento distinto do positivista, para o qual a validação da pesquisa se dá principalmente pela representatividade estatística.

O universo da pesquisa é composto pelos desenvolvedores de software e o lócus é representado por uma instituição de ensino superior do interior de São Paulo. Definiu-se a Faculdade de Tecnologia de Garça (FATEC-Garça), que é uma das poucas instituições públicas de ensino superior a oferecer um curso da área de computação na região de Marília, São Paulo. A região de Marília é estratégica por abrigar um dos cinco Arranjos Produtivos Locais de 


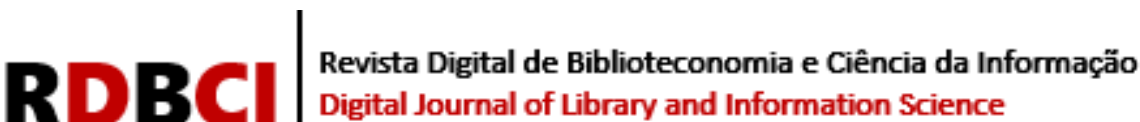

Tecnologia da Informação (APL-TI) do estado (APL-TI MARÍLIA, 2018). A instituição de ensino considerada possui cerca de 1.200 discentes, incluindo os períodos diurno e noturno.

Além da importância estratégica para a região de Marília, justifica-se a escolha do referido lócus pela possibilidade ter acesso a discentes que são colaboradores de diversas organizações, de diferentes municípios, em um mesmo espaço físico. A abordagem no ambiente universitário permitiu um contato direto com os pesquisados, para explicar mais detalhadamente o tema e os objetivos da pesquisa. Enfatiza-se que as FATECs não possuem, segundo informações dos servidores administrativos do campus de Garça, um comitê de ética para lidar com questões específicas de pesquisa acadêmica. Contudo, justifica-se que a presente pesquisa não lidou com grupos humanos em condições de vulnerabilidade, nem envolveu quaisquer procedimentos que pudessem representar danos físicos, psicológicos ou morais aos participantes. Ademais, os participantes concordaram com um Termo de Consentimento Livre e Esclarecido (TCLE), garantindo sigilo de seus dados pessoais, destacando o caráter voluntário de sua colaboração.

Quando às técnicas de coleta de dados utilizou-se o questionário, entrevista e pesquisa documental no período de março a agosto de 2020. Inicialmente, os questionários foram distribuídos para profissionais desenvolvedores de software, que são também estudantes universitários da FATEC-Garça. A primeira etapa da coleta, a aplicação dos questionários, ocorreu presencialmente no início de março de 2020, num momento em que a pandemia COVID-19 não se encontrava em estado tão crítico no Brasil e não havia restrições sanitárias específicas. Isso possibilitou uma breve interação entre pesquisador e pesquisados, a fim de expor o tema de investigação e sua relevância. Os critérios de seleção da amostra intencional da população alvo da pesquisa foram dois: trabalhar atualmente com desenvolvimento de software, quer seja como efetivo ou estagiário, e ter disposição de participar voluntariamente do estudo. Assim, abordou-se os discentes de todos os seis termos ${ }^{1}$ do período noturno do curso de Tecnologia em Análise e Desenvolvimento de Sistemas (ADS), selecionando 12 estudantes, conforme os critérios de amostragem definidos.

O conteúdo do questionário foi elaborado mediante o referencial teórico da presente pesquisa, quanto este convergia com os elementos à serem investigados, como: aspectos egocêntricos e coletivos/altruístas da TTS (BAO; HAN, 2019; CHESHIRE, 2020; CROPANZANO; MITCHELL, 2005; PARK; LEE; LEE, 1999; TSAI; CHENG, 2011; ZOLLER; GARLAND; MULDON, 2019); mediação da informação (ALMEIDA JÚNIOR, 2015; BORTOLIN; LOPES, 2016; GOMES, 2014); gestão do conhecimento (PÉREZ-MONTORO-GUTIÉRREZ, 2008; TAKEUCHI, NONAKA, 2008). Foi enviado por e-mail um questionário on-line utilizando escala de Likert, para inferir suas atitudes e opiniões acerca do compartilhamento e mediação da informação no contexto de trabalho. Os questionários foram encaminhados no e-mail pessoal dos participantes, para responderem quando e onde desejassem, garantindo privacidade e minimizando possíveis pressões externas nas respostas.

A segunda etapa de coleta de dados, a entrevista semiestruturada, foi realizada com servidores administrativos e da direção da FATEC Garça, a fim de apurar critérios de representatividade da unidade de análise, sua relevância no contexto econômico/empresarial regional, bem como as características do corpo discente. Esclarece-se que as entrevistas foram efetuadas no mês de agosto de 2020 e, em virtude do momento crítico da pandemia do

\footnotetext{
${ }^{1}$ Na FATEC denomina-se "termo" o período de um semestre, ao cabo do qual o discente deve efetuar rematrícula. Os cursos tecnológicos oferecidos pela instituição possuem duração de seis termos, ou três anos.
} 


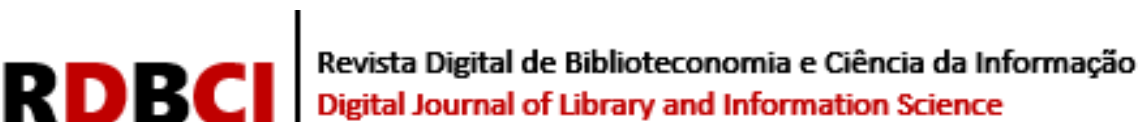

coronavírus no Brasil, e pelas restrições sanitárias impostas pela instituição de ensino, foram realizadas virtualmente, por meio do aplicativo de mensagens WhatsApp.

A terceira etapa da coleta, a pesquisa documental, foi realizada junto ao site da instituição, com o intuito de recuperar informações referentes ao curso de ADS, sobretudo, quanto à matriz curricular, os valores que se busca incutir nos discentes e habilidades que se busca desenvolver.

Deste modo, foi possível realizar a triangulação dos dados. É importante destacar, ainda, algumas questões atinentes às medidas para garantir algum nível de consistência nos dados coletados. Em relação à veracidade das respostas dos pesquisados, destaca-se que, como afirmam Laville e Dionne (1999), nas Ciências Humanas e Sociais, trabalha-se com pessoas, que têm livre arbítrio, valores particulares e um modo peculiar de ver a realidade. Sendo os fatos humanos complexos e variáveis de acordo com épocas, culturas e circunstâncias, é impossível mensurá-los com a precisão das leis da Matemática e das Ciências Naturais, pois a subjetividade do pesquisador e dos pesquisados, pode influenciar nos resultados (LAVILLE; DIONNE, 1999). Ainda segundo os referidos autores, o 'verdadeiro' em Ciências Humanas é relativo e provisório. Assim, não se pode garantir que os sujeitos pesquisados sejam completamente sinceros, mas pode-se utilizar algumas estratégias para garantir um mínimo de coerência nos resultados de pesquisa.

A veracidade dos resultados foi buscada por assegurar o anonimato nas respostas dos pesquisados, além de serem providas instruções pelo pesquisador da importância de que as respostas representassem os reais pensamentos dos respondentes, não havendo necessidade de respostas 'politicamente corretas'.

Quanto à análise e interpretação dos resultados, foram computadas as porcentagens de cada alternativa escolhida referentes às perguntas do questionário, sendo então representados esses cômputos por meio de tabelas e gráficos. A entrevista realizada foi transcrita e seus pontos principais sumarizados e exibidos em forma textual, bem como os resultados da pesquisa documental no site da instituição.

\section{RESULTADOS E DISCUSSÃO}

Inicialmente, é preciso verificar a representatividade da unidade de análise e dos sujeitos pesquisados, para garantir a consistência do estudo de caso efetuado. Segundo a diretora da instituição de ensino e funcionários administrativos entrevistados, dentre os cerca de 1.200 discentes, 138 são do curso de ADS, no período da manhã, e 291 do curso de ADS período noturno. Conforme mencionado, a instituição é a única faculdade pública a oferecer um curso da área de computação na região e, por este motivo, a FATEC atrai estudantes de várias cidades da região, pelo ensino de excelência, que une o rigor científico com uma orientação para o mundo de trabalho, bem como pelo corpo docente qualificado. No curso de ADS, especificamente, estão presentes discentes dos municípios de Marília, Vera Cruz, Garça, Duartina, além dos distritos de Júlio Mesquita e Jafa. Reitera-se que a região de Marília é importante no setor de tecnologia da informação por possuir um dos cinco Arranjos Produtivos Locais de Tecnologia da Informação do Estado de São Paulo (APL-TI MARÍLIA, 2018). Ademais, conforme a diretora, os alunos da FATEC-Garça, estudantes e egressos, têm substancial impacto nos contextos econômico e empresarial da região, pelo seu bom nível de empregabilidade e também pelo seu pendor para o empreendedorismo.

Especificamente em relação ao ensino, além da parte tecnológica em si, os discentes recebem conhecimentos sobre o comportamento e a dinâmica organizacionais, frisando a importância do trabalho em equipe, por meio do compartilhamento da informação e do 


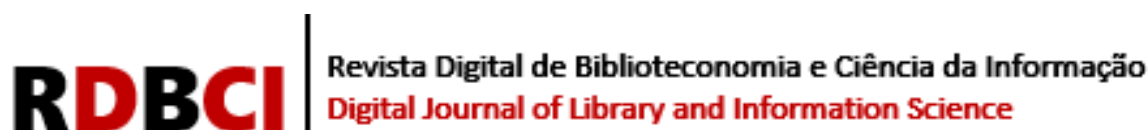

conhecimento. Apoia-se a participação dos discentes em palestras, feiras e cursos de extensão voltado à gestão de pessoas e liderança, como também na matriz curricular há disciplinas voltadas para essa área: Gestão de Equipes, Empreendedorismo e Teoria da Administração.

Essa modalidade de ensino está em consonância com os objetivos do curso, expressos na página on-line da instituição. Busca-se formar profissionais que, além de projetar, desenvolver e manter sistemas de software também sejam "[...] versáteis, dinâmicos, que saibam trabalhar em equipe e possam ter contato com o usuário final do sistema" (FACULDADE DE TECNOLOGIA DE GARÇA, 2020). Assim, é importante inferir se esses valores humanísticos são de fato incorporados pelos estudantes, como isso impacta em sua disposição para compartilhar informação e/ou realizar sua mediação. Deste modo, a seguir é apresentada a compilação das respostas do questionário que aborda esse tema.

\subsection{Fatores egocêntricos e altruístas intervenientes no compartilhamento de informação e conhecimento}

Em relação aos questionários, sua parte inicial versa sobre o perfil das empresas e dos respondentes. Verificou-se que os profissionais de desenvolvimento de software pesquisados trabalham em empresas de diversos nichos, como: softwares para serviços de trânsito; softwares empresariais; e-commerce e marketing; monitoramento e rastreamento; indústria de alimentos. Quanto aos cargos dos respondentes, 07 são profissionais efetivos e 05 estagiários. Dentre os profissionais efetivos: 02 são analistas de suporte e 05 programadores. Referente aos estagiários, 04 atuam com programação e 01 atua na área de inovação. Concernente ao tempo que atuam no desenvolvimento de software, 08 respondentes $(66,7 \%)$ estão na atividade há menos de 01 ano, enquanto 04 (33,3\%) atuam de 01 a 5 anos.

A segunda parte do questionário buscava inferir a motivação dos profissionais para compartilhar informação com os colegas. Foi proposta uma escala de valores ordinais de nível de concordância para as questões, sendo ela: [4] concordo plenamente; [3] concordo parcialmente; [2] não concordo nem discordo; [1] discordo parcialmente; [0] discordo plenamente. Portanto, a Tabela 1 exibe as motivações para o compartilhamento de informação baseadas nos princípios da TTS visando retribuições que beneficiem o compartilhador, ou potencial mediador, de informação e conhecimento, denominadas de egocêntricas na presente pesquisa.

Tabela 1. Motivações egocêntricas e reciprocidade no compartilhamento de informação e conhecimento

\begin{tabular}{|c|c|c|c|c|c|c|}
\hline \multirow{2}{*}{ Afirmativa } & \multicolumn{5}{|c|}{ Escala } & \multirow{2}{*}{$\sum$} \\
\hline & 4 & 3 & 2 & 1 & 0 & \\
\hline $\begin{array}{l}\text { 1. Compartilho informação e } \\
\text { conhecimento para manter uma boa } \\
\text { reputação e/ou status entre meus colegas. }\end{array}$ & $\begin{array}{c}07 \\
{[58,3 \%]}\end{array}$ & $\begin{array}{c}02 \\
{[16,7 \%]}\end{array}$ & $\begin{array}{c}00 \\
{[0,0 \%]}\end{array}$ & $\begin{array}{c}02 \\
{[16,7 \%]}\end{array}$ & $\begin{array}{c}01 \\
{[8,3 \%]}\end{array}$ & $\begin{array}{c}12 \\
{[100,0 \%]}\end{array}$ \\
\hline $\begin{array}{l}\text { 2. Compartilho informação e } \\
\text { conhecimento porque espero que a pessoa } \\
\text { com quem compartilhei faça o mesmo por } \\
\text { mim, como uma troca de favores }\end{array}$ & $\begin{array}{c}04 \\
{[33,3 \%]}\end{array}$ & $\begin{array}{c}04 \\
{[33,3 \%]}\end{array}$ & $\begin{array}{c}02 \\
{[16,7 \%]}\end{array}$ & $\begin{array}{c}02 \\
{[16,7 \%]}\end{array}$ & $\begin{array}{c}00 \\
{[0,0 \%]}\end{array}$ & $\begin{array}{c}12 \\
{[100,0 \%]}\end{array}$ \\
\hline $\begin{array}{l}\text { 3. Compartilho informação e } \\
\text { conhecimento porque acredito que pode } \\
\text { me ajudar a crescer na carreira. }\end{array}$ & $\begin{array}{c}09 \\
{[75 \%]}\end{array}$ & $\begin{array}{c}02 \\
{[16,7 \%]}\end{array}$ & $\begin{array}{c}00 \\
{[0 \%]}\end{array}$ & $\begin{array}{c}01 \\
{[8,3 \%]}\end{array}$ & $\begin{array}{c}00 \\
{[0 \%]}\end{array}$ & $\begin{array}{c}12 \\
{[100 \%]}\end{array}$ \\
\hline $\begin{array}{l}\text { 4. Compartilho informação e } \\
\text { conhecimento porque que quem não o faz } \\
\text { é mal visto pelos colegas }\end{array}$ & $\begin{array}{c}03 \\
{[25 \%]}\end{array}$ & $\begin{array}{c}00 \\
{[0 \%]}\end{array}$ & $\begin{array}{c}05 \\
{[41,7 \%]}\end{array}$ & $\begin{array}{c}03 \\
{[25 \%]}\end{array}$ & $\begin{array}{c}01 \\
{[8,3 \%]}\end{array}$ & $\begin{array}{c}12 \\
{[100 \%]}\end{array}$ \\
\hline
\end{tabular}




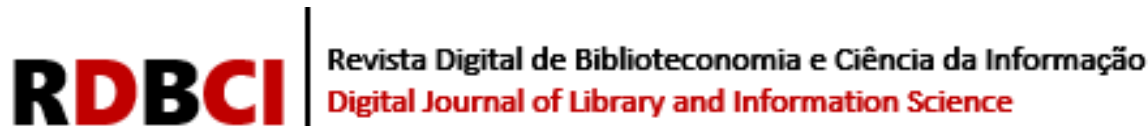

\begin{tabular}{l|c|c|c|c|c|c}
\hline $\begin{array}{l}\text { 5. Compartilho informação e } \\
\text { conhecimento simplesmente porque é } \\
\text { minha obrigação }\end{array}$ & $\begin{array}{c}00 \\
{[0 \%]}\end{array}$ & $\begin{array}{c}03 \\
{[25 \%]}\end{array}$ & $\begin{array}{c}03 \\
{[25 \%]}\end{array}$ & $\begin{array}{c}03 \\
{[25 \%]}\end{array}$ & $\begin{array}{c}03 \\
{[25 \%]}\end{array}$ & $\begin{array}{c}12 \\
{[100 \%]}\end{array}$ \\
\hline
\end{tabular}

Legenda: escala - [4] Concordo plenamente; [3] Concordo parcialmente; [2] Não concordo nem discordo; [1] Discordo parcialmente; [0] Discordo plenamente

Fonte: Elaborado pelos autores (2020).

As motivações para o intercâmbio de informação e, analogamente, de conhecimento, podem ser divididas entre aquelas mais altruístas e as mais egocêntricas. Em conformidade com a afirmação de Pérez-Montoro-Gutiérrez (2008) de que pessoas cedem conhecimento e informação visando manter uma boa reputação, na questão 1 , apurou-se que $58,3 \%$ dos respondentes, a maioria, concorda plenamente com essa visão, enquanto apenas 8,3\%, a minoria, discorda plenamente. Nenhum respondente escolheu a alternativa neutra, "não concordo nem discordo', mostrando uma clara tendência de concordância total.

Em relação ao princípio de reciprocidade da TTS (CROPANZANO; MITCHELL, 2005; GIFT EXCHANGE, 2020; ZOLLER; GARLAND; MULDON, 2019), na questão 2, indagou-se se os respondentes encarariam a troca de informação e conhecimento como uma troca de favores, esperando uma devolutiva direta no futuro. Os respondentes se mostraram mais divididos sobre a questão, mas com uma tendência ligeiramente maior em concordar. $33,3 \%$ concordaram plenamente e parcialmente; $16,7 \%$ deram resposta neutra. $16,7 \%$ discordaram parcialmente. Não houve discordâncias plenas.

$\mathrm{Na}$ questão 3, quando perguntados se os respondentes compartilham informação/conhecimento visando um crescimento na carreira, que seria também uma forma de reciprocidade direta, a maioria contundente, $75 \%$, concordou plenamente, não tendo havido respostas neutras nem discordâncias plenas, apenas $8 \%$ que discordaram parcialmente. Essa questão se baseia no fato apurado por Pérez-Montoro-Guitérrez (2008, p. 101, tradução nossa) de que uma das consequências (reciprocidade) esperadas pelo sujeito que compartilha conhecimento pode ser "[...] segurança laboral, promoção pessoal ou aumento de salário [...]", consequência da boa reputação que passa a gozar como compartilhador.

Na questão 4, de acordo com as conclusões de Pérez-Montoro-Gutiérrez (2008), foi indagado se evitar ser mal visto pelos colegas seria um motivador para intercambiar conhecimento e informação. Houve uma preponderância de respostas neutras $(41,7 \%)$, e também uma maior tendência para as respostas negativas.

Por fim, na questão 5, quando indagados se compartilhariam informação e conhecimento simplesmente por ser sua obrigação, os respondentes ficaram bastante divididos, não podendo ser identificada nenhuma tendência maior para respostas positivas ou negativas, mostrando que não há consenso a respeito.

A Tabela 2 enfatiza as motivações mais altruístas e as baseadas na troca generalizada, na qual o sujeito não espera necessariamente uma devolutiva imediata e direta, mas efetua a 'boa ação' em benefício da coletividade, o que também pode beneficiá-lo, mas indiretamente, como membro do grupo (CHESHIRE, 2020; TSAI; CHENG, 2011).

Tabela 2. Motivações grupais/altruístas no compartilhamento da informação e do conhecimento.

\begin{tabular}{|c|c|c|c|c|c|c|}
\hline \multirow{2}{*}{ Afirmativa } & \multicolumn{5}{|c|}{ Escala } & \multirow{2}{*}{$\Sigma$} \\
\hline & 4 & 3 & 2 & 1 & 0 & \\
\hline $\begin{array}{l}\text { 6. Compartilho informação e conhecimento } \\
\text { porque na minha empresa todos se ajudam } \\
\text { mutuamente e futuramente alguém pode } \\
\text { compartilhar informação comigo quando eu } \\
\text { precisar. }\end{array}$ & $\begin{array}{c}08 \\
{[66,7 \%]}\end{array}$ & $\begin{array}{c}03 \\
{[25 \%]}\end{array}$ & $\begin{array}{c}01 \\
{[8,3 \%]}\end{array}$ & $\begin{array}{c}00 \\
{[0 \%]}\end{array}$ & $\begin{array}{c}00 \\
{[0 \%]}\end{array}$ & $\begin{array}{c}12 \\
{[100,0 \%]}\end{array}$ \\
\hline
\end{tabular}




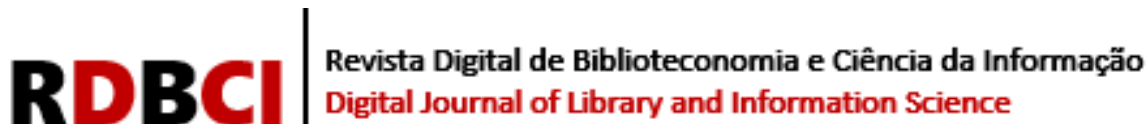

\begin{tabular}{l|c|c|c|c|c|c}
\hline $\begin{array}{l}\text { 7. Compartilho informação e conhecimento } \\
\text { porque sinto satisfação pessoal, prazer, em } \\
\text { compartilhar com outros aquilo que sei }\end{array}$ & $\begin{array}{c}07 \\
{[58,3 \%]}\end{array}$ & $\begin{array}{c}04 \\
{[33,3 \%]}\end{array}$ & $\begin{array}{c}01 \\
{[8,3 \%]}\end{array}$ & $\begin{array}{c}00 \\
{[0 \%]}\end{array}$ & $\begin{array}{c}00 \\
{[0 \%]}\end{array}$ & $\begin{array}{c}12 \\
{[100,0 \%]}\end{array}$ \\
\hline $\begin{array}{l}\text { 8. Compartilho informação e conhecimento } \\
\text { com as pessoas que tenho amizade, } \\
\text { recebendo ou não algo em troca }\end{array}$ & $\begin{array}{c}09 \\
{[75 \%]}\end{array}$ & $\begin{array}{c}02 \\
{[16,7 \%]}\end{array}$ & $\begin{array}{c}01 \\
{[8,3 \%]}\end{array}$ & $\begin{array}{c}00 \\
{[0 \%]}\end{array}$ & $\begin{array}{c}00 \\
{[0 \%]}\end{array}$ & $\begin{array}{c}12 \\
{[100 \%]}\end{array}$ \\
\hline
\end{tabular}

Legenda: escala - [4] Concordo plenamente; [3] Concordo parcialmente; [2] Não concordo nem discordo; [1] Discordo parcialmente; [0] Discordo plenamente

Fonte: Elaborado pelos autores (2020).

Na questão 6, que aborda especificamente a troca generalizada, a maioria dos respondentes foram positivos em afirmar que "compartilho informação e conhecimento porque na minha empresa todos se ajudam mutuamente e futuramente alguém pode compartilhar informação comigo quando eu precisar". Assim, 66,7\% concordaram plenamente com essa proposição e $25 \%$ concordaram parcialmente. Não houve discordâncias, plenas ou parciais.

Referente à questão 7, quando inquiridos se o motivo principal de compartilhar informação e conhecimento seria uma satisfação pessoal, novamente, a maioria foi positiva: $58,3 \%$ concordaram plenamente e $33,3 \%$ parcialmente, não havendo discordâncias. Argumenta-se que essa postura pode ser decorrente tanto de valores pessoais que o sujeito incorporou ao longo da vida, como também consequência de um senso desenvolvido de autoeficácia, que é a crença na própria capacidade de realização e construção de conhecimento (BANDURA, 1978; BAO; HAN, 2019).

Analogamente, na questão 8, "compartilho informação e conhecimento com as pessoas que tenho amizade, recebendo ou não algo em troca": $75 \%$ concordaram plenamente; $16,7 \%$ parcialmente; $8,3 \%$ deram resposta neutra e não houve discordâncias. Esses resultados reforçam as conclusões da TTS no sentido de que o amor/amizade podem ser em si mesmos uma recompensa importante para o sujeito que cede seus conhecimentos a outrem (FOA; FOA, 1974, 1980 apud CROPANZANO; MITCHELL, 2005; LAWLER; TYE, 1999). Contudo, esse comportamento positivo só é possível em contextos organizacionais harmoniosos, em que os gestores demonstram interesse genuíno no bem-estar dos colaboradores (SOUZA, MORAES, 2018; TAKEUCHI; NONAKA, 2008).

Considerados os impactos dos fatores tanto egocêntricos, isto é, voltados à reciprocidade direta em benefício do compartilhador de informação e conhecimento, bem como os fatores altruístas e voltados ao bem-estar coletivo, é pertinente examinar aspectos mais específicos da relação da TTS com a mediação da informação na perspectiva dos sujeitos pesquisados.

\subsection{Convergência entre a TTS e a mediação da informação e do conhecimento}

$\mathrm{Na}$ Tabela 3 são exibidas as respostas para as perguntas que tratam mais especificamente da disposição dos respondentes para realizar a mediação da informação/conhecimento, isto é, uma preocupação genuína de que o receptor tenha condições de se apropriar da informação. Reitera-se que "[...] trabalhar com a informação não é simplesmente disponibilizá-la" (BORTOLIN; CRUZ, 2016, p. 120).

Tabela 3. Aspectos referentes à mediação da informação e do conhecimento.

\begin{tabular}{|c|c|c|c|c|c|c|}
\hline \multirow{2}{*}{ Afirmativa } & \multicolumn{5}{|c|}{ Escala } & \multirow[t]{2}{*}{$\sum$} \\
\hline & 4 & 3 & 2 & 1 & 0 & \\
\hline $\begin{array}{l}\text { 9. Quando compartilho informação e conhecimento } \\
\text { com alguém sempre me certifico que a pessoa } \\
\text { conseguirá entender essa informação, de que sua } \\
\text { linguagem e/ou conceitos são compreensíveis para } \\
\text { ela }\end{array}$ & $\begin{array}{c}08 \\
{[66,7 \%]}\end{array}$ & $\begin{array}{c}03 \\
{[25 \%]}\end{array}$ & $\begin{array}{c}01 \\
{[8,3 \%]}\end{array}$ & $\begin{array}{c}00 \\
{[0 \%]}\end{array}$ & $\begin{array}{c}00 \\
{[0 \%]}\end{array}$ & $\begin{array}{c}12 \\
{[100 \%]}\end{array}$ \\
\hline
\end{tabular}




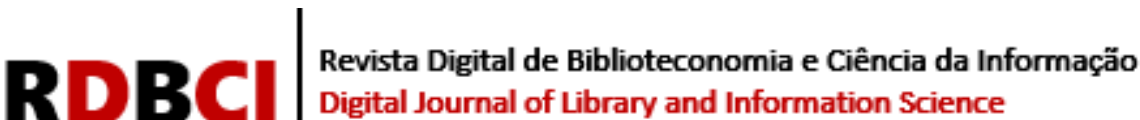

\begin{tabular}{l|c|c|c|c|c|c}
$\begin{array}{l}\text { 10. Sempre tento compreender o melhor possível o } \\
\text { problema/necessidade de meu colega, para } \\
\text { compartilhar com ele(a) informações e } \\
\text { conhecimentos que acredito serem de fato úteis para } \\
\text { resolvê-lo. }\end{array}$ & $\begin{array}{l}11 \\
{[91,7 \%]}\end{array}$ & $\begin{array}{c}01 \\
{[8,3 \%]}\end{array}$ & 00 & 00 & 00 & 12 \\
\hline
\end{tabular}

Legenda: escala - [4] Concordo plenamente; [3] Concordo parcialmente; [2] Não concordo nem discordo; [1] Discordo parcialmente; [0] Discordo plenamente

Fonte: Elaborado pelos autores (2020).

A questão 09 indaga se o respondente, ao compartilhar informação e conhecimento, se preocupa de que esta seja compreensível ao receptor, se a linguagem é adequada a ele, se os conceitos subjacentes são compreendidos. Neste aspecto, existe uma tendência clara para a concordância, onde: $66,7 \%$ concordam plenamente; $25 \%$ parcialmente; $8,3 \%$ foram neutros e não houve discordâncias. Neste aspecto, o trabalho de mediação é uma ação personalizada, que leva em conta o nível cognitivo do sujeito, seu arcabouço pessoal de saberes prévios, sendo, portanto, um ato de apreço pelo receptor da informação, um esforço que exige conhecer bem o outro. Esse nível de estreitamento dos laços sociais, amizade, coleguismo, é justamente o pré-requisito fundamental para a TTS. Este é um processo cíclico, em que o conhecimento pré-existente ajuda a compreender a informação, que, por sua vez, ajuda a formar o novo conhecimento.

A assimilação da informação difere de indivíduo para indivíduo. Se dez pessoas lerem o mesmo texto, no mesmo espaço, e ao mesmo tempo, cada uma vai ter uma versão diferente do texto, sugerindo que cada uma, com seu pré-conhecimento tácito sobre o assunto, agrupa as informações já existentes na sua memória com as novas, transformando tudo em um novo conhecimento [...] (FACHIN, 2013, p. 29).

Essa indagação é pertinente, visto que, para Almeida Júnior (2015), a informação não existe a priori; o que existe é um conjunto de dados, uma 'protoinformação', que só se torna real informação no momento em que é compreendida pelo sujeito. Analogamente, poderia se dizer que um livro num idioma ignorado se constitui apenas protoinformação, pois é um conjunto de dados que, contudo, o sujeito não está apto a usar para satisfazer suas necessidades informacionais.

A questão 10 verifica se os pesquisados buscam compreender a necessidade informacional ou problema dos colegas, para então compartilhar com eles informações que sejam efetivamente úteis para resolvê-los. Para Almeida Júnior (2015), uma das principais funções do mediador é identificar a necessidade informacional dos sujeitos, ainda que essa necessidade, por vezes, não seja claramente explicitada. Por vezes, afirma Taylor (1967), o sujeito tem apenas um sentimento de inadequação, de que algo falta para concretizar seu intento, mas que não sabe exatamente o quê. A este tipo de necessidade informacional, este autor (1967) denomina necessidade visceral. Aí deve entrar toda a experiência e sensibilidade do mediador para interpretar as pistas dadas pelo potencial receptor da informação, o que não é tarefa fácil. Por fim, é preciso expor que, para Almeida Júnior (2015), a necessidade informacional nunca é totalmente satisfeita, porque a assimilação de uma informação pode gerar novas necessidades, novas dúvidas e inquietações.

As respostas à questão 10 foram as seguintes: 91,7\% concordaram plenamente; 8,3\% concordaram parcialmente; não houve respostas neutras nem discordâncias parciais ou plenas. Assim, as respostas mostram que a unanimidade dos pesquisados se esforça para efetuar uma real mediação da informação, não apenas repassar ou transferir informação. Essa constatação mostra a necessidade da ampliação da compreensão da existência da mediação fora dos equipamentos informacionais tradicionais, bibliotecas, arquivos e museus. Essa ampliação é tanto mais pertinente quando se constata que o conceito de mediação bebe da fonte de várias 


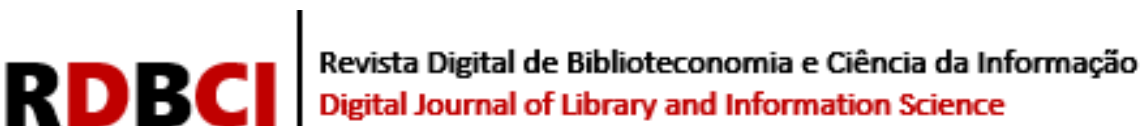

disciplinas além da Biblioteconomia e da CI. "A interdisciplinaridade da área permite o trânsito entre as fronteiras epistemológicas, fazendo assim que o conceito de Mediação flane por diversos métodos" (BORTOLIN; LOPES, 2016, p. 123).

Como apontado por Souza (2019), os desenvolvedores de software utilizam a Internet como uma de suas principais fontes informacionais. Contudo, Fachin (2013) reconhece que existe uma profusão gigantesca de conteúdo da web e que o mediador pode ser útil, para ajudar a outros, usando sua experiência, a navegar nesse corpus informacional, auxiliando na recuperação da informação mais relevante, de maneira eficaz e em tempo oportuno.

Portanto, considera-se, pelos dados apresentados e discutidos, que a mediação efetiva da informação é uma possibilidade também fora dos equipamentos informacionais tradicionais. Além disso, apurou-se que os respondentes têm uma maior tendência a apresentar comportamentos de viés mais altruísta, que levam em conta o benefício do grupo e as relações de amizade. Essa tendência positiva para colaborar com os colegas e com a organização compartilhando/ mediando conhecimento e informação ocorre a despeito de a literatura científica apontar a existência de barreiras como: desconfiança, monopólio de informação e clima organizacional negativo (DAVENPORT; PRUSAK, 1998; CHIAVENATO, 2003). Contudo, uma possível explicação para os resultados preponderantemente positivos da presente pesquisa pode estar tanto na existência de um ambiente organizacional favorável em que os pesquisados trabalham, como em valores de cooperação aprendidos e reforçados no contexto da graduação. Esses valores, passados pela instituição de ensino, como já apresentado, enfatizam as dinâmicas do comportamento organizacional e o trabalho em equipe.

Ademais, também existe um aspecto expressivo de busca pela reciprocidade direta, pois $75 \%$ dos pesquisados responderam que compartilham informação e conhecimento esperando que isto possa ajudá-los a crescer na carreira. Aqui, o egocentrismo e o altruísmo, fatores aparentemente antagônicos, coexistem e se completam na perspectiva dos profissionais. Este fenômeno está em consonância com a observação de Takeuchi e Nonaka (2008), de que o conhecimento organizacional é inerentemente formado de contradições, entre tácito e explícito, topo da hierarquia e base, e afins. Numa perspectiva dialética, estes autores (2008) afirmam que a contradição não deve ser extirpada, mas cultivada, como elemento gerador de mudança e inovação. A dialética, na visão do filósofo alemão G. W. F. Hegel tem como princípio básico que "todas as coisas contêm lados ou aspectos contraditórios, cuja tensão ou conflito é a força motriz da mudança e eventualmente os transforma ou dissolve" (DIALECTICAL MATERIALISM, 2020, tradução nossa, não paginado).

\section{CONSIDERAÇÕES FINAIS}

Em suma, considera-se que as evidências coletadas apontam para a existência de uma mediação efetiva da informação entre os desenvolvedores de software pesquisados. Ademais, verificou-se que as motivações para essa mediação são mais voltadas às trocas sociais com enfoque na coletividade e na amizade. Contudo, foi também expressiva a proporção de pesquisados que afirmaram compartilhar informação e conhecimento visando crescimento na carreira, o que configura uma busca por reciprocidade direta, o que se definiu na presente pesquisa como motivação egocêntrica. Assim, motivações altruístas e egocêntricas, aparentemente contraditórias, se conciliam dialeticamente para colaborar com o compartilhamento/mediação da informação e do conhecimento organizacionais.

Ademais, a revisão de literatura realizada expôs a existência de fatores que representam potenciais barreiras ao compartilhamento da informação e do conhecimento, como: desconfiança, monopólio informacional e insatisfação no trabalho. Contudo, os 


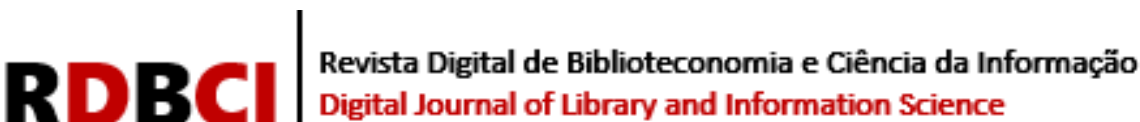

resultados da presente pesquisa mostraram uma tendência preponderante para o compartilhamento de informação e conhecimento e espírito colaborativo entre os pesquisados.

Como discutido ao longo do trabalho, os resultados positivos com enfoque mais altruísta podem ter suas raízes na assimilação de valores éticos/morais aprendidos, como também uma resposta a um contexto de trabalho em que as necessidades dos colaboradores são levadas em conta, gerando um clima organizacional positivo. Embora o questionário não revele aspectos específicos do contexto de trabalho dos respondentes, a pesquisa verificou outro fator importante para a internalização de valores positivos em relação aos colegas e a organização, que é a formação acadêmica. Apurou-se que existe um esforço da instituição de ensino investigada em aliar a formação tecnológica a uma sensibilidade para a compreensão das dinâmicas do comportamento e contexto organizacionais. Isto acaba por formar um profissional diferenciado, que possui habilidades humanísticas que são imprescindíveis para o trabalho em equipe e relacionamento harmonioso com os colegas, influenciando indiretamente na eficácia e produtividade, que advém da mediação efetiva da informação.

Conclui-se que existem convergências entre a TTS e a mediação da informação tanto no aspecto teórico quanto prático, sobretudo, quando se analisam os fatores que levam ao compartilhamento, em especial, a motivação altruísta. Contudo, infere-se que motivadores egocêntricos, voltados ao benefício próprio, podem coexistir com esses motivadores altruístas. Como limitação do trabalho destaca-se, principalmente, o tamanho relativamente pequeno da amostra. Contudo, argumenta-se que a reunião de várias fontes de evidência sobre o tema estudado pôde trazer maior consistência aos resultados. Embora não se possa fazer uma generalização estatisticamente rigorosa do estudo, este contribui qualitativamente com a área de CI, desvelando as perspectivas informacionais de um relevante nicho profissional, apontado para a possiblidade da mediação da informação fora dos equipamentos informacionais tradicionais: as bibliotecas, arquivos e museus. Como pesquisas futuras, recomenda-se a aplicação de pesquisas com profissionais formados na área de Análise e Desenvolvimento de Sistemas, Sistemas de Informação e Ciência da Computação, numa dimensão mais ampla e com lócus ampliado.

\section{REFERÊNCIAS}

ALMEIDA JÚNIOR, Oswaldo Francisco de. Mediação da informação: um conceito atualizado. In: BORTOLIN, Sueli.; SANTOS NETO, João Arlindo dos; SILVA, Rovilson José. (org.). Mediação oral da informação e da leitura. Londrina: ABECIN, 2015. p. 9- 32.

APL-TI MARÍLIA. História do APL TI Marília. Marília: 2018. Disponível em:

http://www.apltimarilia.org.br/historia-do-apl-ti-marilia-arranjo-produtivo-local-de-tecnologia-dainformacao-de-marilia/. Acesso em: 17 jul. 2018.

ASSOCIAÇÃO BRASILEIRA DAS EMPRESAS DE SOFTWARE. Setor cresce no Brasil 10,5\% em 2019. São Paulo: ABES, 2020. Disponível em:

https://abessoftware.com.br/dados-do-setor/. Acesso em: 30 set. 2020.

BANDURA, Albert. Self-efficacy: Toward a unifying theory of behavioral change. Advances in Behaviour Research and Therapy, v. 1, n. 4, p. 139-161, 1978. Disponível em: https://doi.org/10.1016/0146-6402(78)90002-4. Acesso em: 27 set. 2020. 


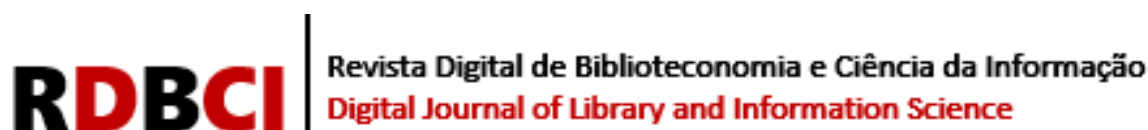

BAO, Z.; HAN, Z. What drives users' participation in online social Q\&A communities? An empirical study based on social cognitive theory. Aslib Journal of Information Management. v. 71, n. 5, p. 637-656, 2019. Disponível em: https://doi.org/10.1108/AJIM-01-2019-0002. Acesso em: 07 fev. 2020.

BORTOLIN, Sueli; LOPES, Fernando Cruz. A percepção de pesquisadores da ciência da informação quanto aos conceitos de mediação. Revista Interamericana de Bibliotecología, Colômbia, v. 39, n. 2, p. 121-132, 2016. DOI: 10.17533/udea.rib.v39n2a04 Acesso em: 25 ago. 2020.

BUCKLAND, Michael Keeble. Information as thing. Journal of the American Society for Information Science, v.45, n.5, p. 351-360, 1991. Disponível em: https://www.cin.ufpe.br/ cjgf/TECNOLOGIA\%20-\%20material\%20NAO-CLASSIFICADO/ Informacao\%20como\%20Coisa\%20(thing).pdf. Acesso em: 26 ago. 2020.

CHESHIRE, Coye. Generalized exchange. In: Britannica Academic. [S.1.]: Encyclopædia Britannica, 2020. Não paginado. Disponível em:

https://academic.eb.com/levels/collegiate/article/generalized-exchange/600926. Acesso em: 26 ago. 2020.

CHIAVENATO, Idalberto. Introdução à Teoria Geral da Administração: uma visão abrangente da moderna administração das organizações. 7.ed. Rio de Janeiro: Elsevier, 2003.

CROPANZANO, Russel.; MITCHELL, Mary S. Social Exchange Theory: An Interdisciplinary Review. Journal of Management, v. 31, n. 6, p. 874-900, dez. 2005. Disponível em: https://doi.org/10.1177/0149206305279602. Acesso em: 27 jul. 2020.

DAVENPORT, Thomas H.; PRUSAK, L. Ecologia da informação: porque só a tecnologia não basta para o sucesso na era da informação. São Paulo: Futura, 1998.

DIALECTICAL MATERIALISM. In: Britannica Academic. [S.1.]: Encyclopædia Britannica, 2020. Disponível em: https://academic.eb.com/levels/collegiate/article/dialecticalmaterialism/30255. Acesso em: 30 set. 2020.

FACHIN, Juliana. Mediação da informação na sociedade do conhecimento. Biblos: Revista do Instituto de Ciências Humanas e da Informação, v. 27, n. 1, p. 25-41, jan./jun. 2013. Disponível em: https://periodicos.furg.br/biblos/article/view/3096/2390 . Acesso em: 20 ago. 2020.

FACULDADE DE TECNOLOGIA DE GARÇA. Cursos: Tecnologia em Análise e Desenvolvimento de Sistemas. Garça, SP: Centro Paula Souza, 2020. Disponível em: http://fatecgarca.edu.br/ads. Acesso em: 27 jul. 2020.

GIFT EXCHANGE. In: Britannica Academic. [S.1.]: Encyclopædia Britannica, 2020.

Disponível em: https://academic.eb.com/levels/collegiate/article/gift-exchange/36782. Acesso em: 27 jul. 2020.

GIL, Antônio Carlos. Métodos e técnicas de pesquisa social. 2.ed. São Paulo: Atlas, 2008. 


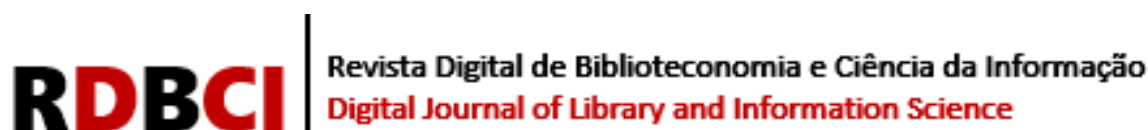

GOMES, Henriette Ferreira. A dimensão dialógica, estética, formativa e ética da mediação da informação. Informação \& Informação, v. 4, n. 2, p. 46-59, maio/ago. 2014. Disponível em: http://dx.doi.org/10.5433/1981-8920.2014v19n2p46. Acesso em: 20 ago. 2020.

LAVILLE, C.; DIONNE, J. A construção do saber: manual de metodologia da pesquisa em ciências humanas. Porto Alegre: Artmed, 1999.

LAWLER, Edward J.; THYE, Shane R. Bringing emotions into social exchange theory. Annual Review of Sociology, v. 25, p. 217-244, ago. 1999. Disponível em: https://doi.org/10.1146/annurev.soc.25.1.217. Acesso em: 27 jul. 2020.

MARCHAND, Donald A.; KETTINGER, William J.; ROLLINS, John D. Information orientation: The link to business performance. Oxford: Oxford University Press, 2001.

MORAES, Cássia Regina Bassan de; SOUZA, Leonardo Pereira Pinheiro de. Mapeamento da literatura internacional sobre o mercado do conhecimento nas organizações. In: ENCONTRO NACIONAL DE PESQUISA EM CIÊNCIA DA INFORMAÇÃO. 20., 2019, Florianópolis. Anais [...]. Florianópolis: ANCIB, 2019. p. 1-21. Disponível em: https://conferencias.ufsc.br/index.php/enancib/2019/paper/view/867/871. Acesso em: 30 set. 2020.

PARK, Jun-Gi.; LEE, Hyejung; LEE, J Jungwoo. Applying social exchange theory in IT service relationships: exploring roles of exchange characteristics in knowledge sharing.

Information Technology and Management, v. 16, n. 3, p. 193-206, set. 2015. Disponível em: https://doi.org/10.1007/s10799-015-0220-x. Acesso em: 27 jul. 2020.

PÉREZ-MONTORO-GUTIÉRREZ, Mario. Gestión del conocimiento en las organizaciones: fundamentos, metodología y praxis. Gijón (Asturias): Ediciones Trea, 2008.

SOMMERVILLE, Ian. Engenharia de software. 8.ed. São Paulo: Pearson Education, 2007.

SOUZA, Leonardo Pereira Pinheiro de. O comportamento informacional dos desenvolvedores de software no contexto da cultura organizacional enfatizando o compartilhamento e reuso de informações. 2019. 287 f. Dissertação (Mestrado em Ciência da Informação) - Faculdade de Filosofia e Ciências, Universidade Estadual Paulista, Marília, 2019. 287 p.

SOUZA, Leonardo Pereira Pinheiro de; MORAES, Cássia Regina Bassan de. Influência do clima organizacional para o compartilhamento de conhecimento tácito no desenvolvimento de software. In: ENCONTRO SOBRE CIÊNCIA, TECNOLOGIA E GESTÃO DA INFORMAÇÃO, 8., 2018, Recife. Anais... Recife: Universidade Federal de Pernambuco, 2018. p. 132- 144. Disponível em:

https://drive.google.com/file/d/1iHNGQM8IIGV-9hXkYhCgRfA2r-0rhPkl/view. Acesso em: 31 mar. 2019.

TAKEUCHI, Hirotaka; NONAKA, Ikujiro. Gestão do conhecimento. Porto Alegre: Bookman, 2008. 


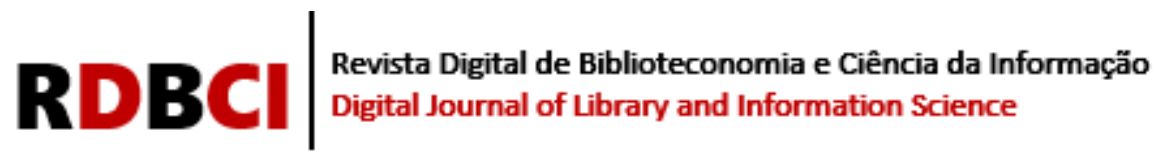

TAYLOR, R. S. Question negotiation and information seeking in libraries. Bethlehem (PA): Center for the Information Sciences Lehigh University, 1967. Disponível em: http://www.dtic.mil/dtic/tr/fulltext/u2/659468.pdf. Acesso 19 jan 2018.

TERRETT, Andrew. Knowledge Management and the Law Firm. Journal of Knowledge Management; v. 2, n. 1, p. 67-76, 1998. Disponível em:

https://doi.org/10.1108/EUM0000000004608. Acesso em: 28 jul. 2019.

TSAI, Ming-Tien; CHENG, Nai-Chang. Understanding knowledge sharing between IT professionals - an integration of social cognitive and social exchange theory. Behaviour $\&$ Information Technology, v. 31, n. 11, p. 1069-1080, 2012.Disponível em: https://doi.org/10.1080/0144929X.2010.550320. Acesso em: 27 jul. 2020.

YIN, Robert K. Case study research: design and methods. 4. ed. Thousand Oaks (CA): SAGE, 2009.

ZOLLER, Yaron J.; SCHILCUTT, J. Garland.; MULDOON, Jeff. Illuminating the principles of social exchange theory with Hawthorne studies. Journal of Management History, v. 25, n. 1, 2019, p. 47-66. Disponível em: https://doi.org/10.1108/JMH-05-2018-0026. Acesso em: 27 jul. 2020. 


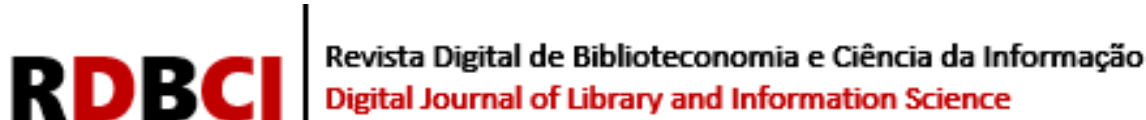

Artigo submetido ao sistema de similaridade 